\title{
Mucormycosis in COVID-19: A systematic review of literature
}

\author{
Shivaraj Nagalli', Nidhi Shankar Kikkeri² \\ 1Department of Internal Medicine, Brookwood Baptist Health, Alabaster, USA; \\ ${ }^{2}$ Department of Neurology, University of Alabama, Birmingham, USA
}

Article received 1 October, 2021; accepted 20 October, 2021

\section{SUMMARY}

Coronavirus disease 2019 (COVID-19) is an acute viral illness caused by severe acute respiratory syndrome coronavirus-2 (SARS-CoV-2). Opportunistic infections such as mucormycosis have been reported among COVID-19 patients particularly in South Asian countries during the second wave of this pandemic. It is necessary to re-evaluate any changes in traditional risk factors associated with mucormycosis such as diabetes mellitus, organ transplant, etc in the precedent of ongoing COVID-19 pandemic. We conducted a systematic review using electronic databases. A total of 115 COVID-19 patients who were diagnosed with mucormycosis were included in this study. Diabetes mellitus was the most common co-morbidity with $77.1 \%$, followed by hypertension $(29.5 \%)$ and renal disease $(14.3 \%) .55 .2 \%$ of the patients had received dexamethasone for COVID-19 infection. Ten patients (11.5\%) had received tocilizumab.

Sinuses were the most common site of mucormycosis among COVID-19 patients at $79.4 \%$ with maxillary sinus $(47.4 \%)$ being most commonly infected. Orbits were the second most prevalent site at $56.7 \%$ and lungs were infected with mucor at $11.3 \%$. The mean duration between the diagnosis of COVID-19 infection and mucormycosis was 16.15 days (range 2-90 days). Cavernous sinus was either infiltrated or encased in 14 patients $(14.4 \%)$. Cerebral involvement was seen in terms of abscess, infarcts, or edema in 12 patients (12.4\%). Only 76 patients had data on the outcomes, out of which 37 $(48.7 \%)$ patients had died. Diabetes mellitus is still the most common co-morbidity similar to non-COVID-19 patients. More than $90 \%$ of the patients with COVID-19 infection had received steroids. Complications such as cavernous sinus thrombosis, cerebral infarcts, abscesses were common. Indiscriminate use of steroids in patients needs to be avoided and focus needs to be put on tight blood sugar control in diabetic patients. Studies are needed to confirm the role of the SARS-CoV-2 virus in causing immune dysfunction and mucormycosis.

Keywords: Mucormycosis, COVID-19, steroids, diabetes mellitus, sinus.

\section{INTRODUCTION}

C oronavirus disease 2019 (COVID-19) is an acute viral illness caused by severe acute respiratory syndrome coronavirus-2 (SARS-CoV-2). SARS-CoV-2 is a single stranded RNA beta coronavirus that belongs to Coronaviridae family. Ever since its first detection in Wuhan, China in November 2019, SARS-CoV-2 has infected over 230 million people causing more than 4.8 million

Corresponding author

Shivaraj Nagalli

E-mail: shivanagalli21@gmail.com deaths worldwide as of the 12th of Oct 2021, and the numbers are increasing [1].

Dexamethasone has been the treatment of choice in COVID-19 pneumonia with hypoxia ever since the REMAP study demonstrated its effectiveness in reducing mortality [2]. Since then, the use of steroids has tremendously increased. This presets the ground for the emergence of opportunistic infections. Cases of several opportunistic infections such as candidiasis, aspergilloma, and mucormycosis are increasingly reported in association with COVID-19 infections. The risk and prevalence of mucormycosis among COVID-19 patients are currently unknown. During the pre-pandemic era, the global cases of mucormycosis varied from 0.005 to 
1.7 per million population [3]. Some South Asian countries such as India have seen a tremendous increase in the cases of mucormycosis, particularly during the second wave of pandemic. It is necessary to evaluate any changes in the prevalence of traditional risk factors associated with mucormycosis such as diabetes mellitus, organ transplant, etc and to study the novel risk factors to appropriately mitigate one's risk of developing this deadly fungal infection among COVID-19 patients. Hence, we conducted a systematic review of the literature to study the patient's characteristics, risk factors, complications, and outcomes of COVID-19 patients diagnosed with mucormycosis.

\section{PATIENTS AND METHODS}

We searched the electronic databases PubMed, Embase, and Google Scholar from inception until June 21, 2021, using keywords "COVID-19", "Coronavirus disease-2019", "SARS-CoV-2" and "Mucormycosis", "Mucor", "Zygomycosis".

Inclusion criteria were set as follows:

- all case reports and case series with a diagnosis of mucormycosis or zygomycosis were included using the above search criteria;
- patients should have been diagnosed with COVID-19 either before or at the time of diagnosis of mucormycosis.

Exclusion criteria were set as follows:

- articles other than case reports, case series such as reviews, systematic reviews, and editorials were excluded;

- articles with non-English literature were excluded.

The details of individual cases reported were retrieved, reviewed, and analyzed. The flow chart explaining the method of selection of articles is as shown in Figure 1.

\section{RESULTS}

A total of 36 articles consisting of 115 patients were included in this review [4-39]. The results of our systematic review are as compiled in Table 1. The patient's baseline characteristics and presenting symptoms are reported in Table 2. Most cases were reported from India at $49.6 \%$, followed by Iran (15.6\%) and Turkey (9.6\%). Nine cases $(7.8 \%)$ were reported from the United States, 8 cases $(6.9 \%)$ were reported in Egypt, 4 (3.5\%) in

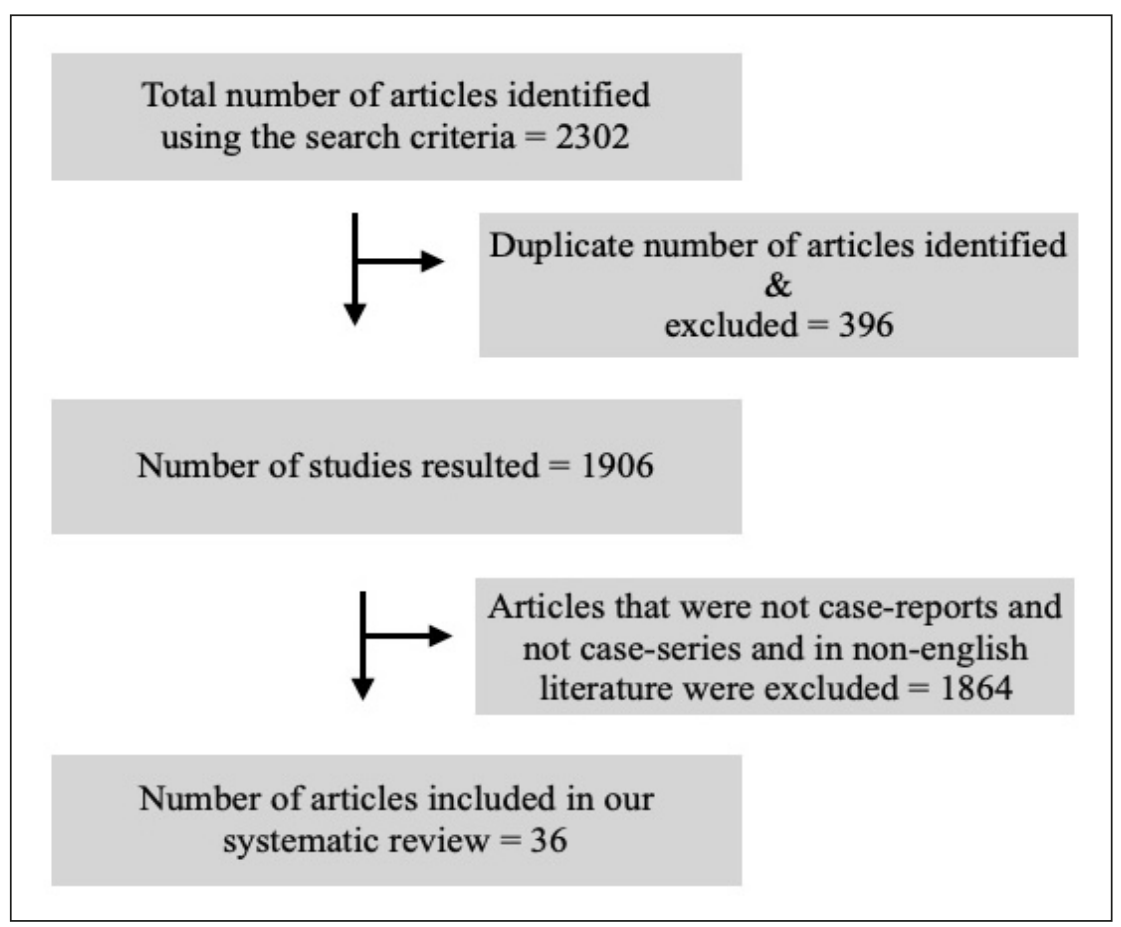

Figure 1 - Flow chart explaining the selection of the articles used in our systematic review. 
the Netherlands, $2(1.7 \%)$ in Spain, and one case in Austria, Mexico, France, UK, Italy, and Mexico.

\section{Demographics and co-morbidities}

The average age of the patients was 54.9 years (1488 years); $77.4 \%$ were male. We found that diabetes mellitus was the most common co-morbidity with
$77.1 \%$, followed by hypertension (29.5\%). Diabetic ketoacidosis (DKA) was found in 11 patients $(9.6 \%)$ either at the time of admission or during hospitalization. The average HbA1C (glycosylated hemoglobin) level was $10.1 \%$. Renal disease was reported in $14.3 \%$ of patients, out of whom 3 patients $(2.8 \%)$ had end-stage renal disease. Seven $(6.7 \%)$

Table 1 - Results of systematic review of patients with mucormycosis \& COVID-19.

\begin{tabular}{|c|c|}
\hline Parameters & Results \\
\hline $\begin{array}{l}\text { Age (average, } \\
\text { range) }\end{array}$ & 54.9 years ( 14 - 88 years) \\
\hline Sex & $\begin{array}{l}\text { M: } 89(77.4 \%) \\
\text { F: } 26(22.6 \%)\end{array}$ \\
\hline $\begin{array}{l}\text { Geographic } \\
\text { location }\end{array}$ & $\begin{array}{l}\text { India: } 57(49.6 \%) \\
\text { Iran: } 18(15.6 \%) \\
\text { Turkey: } 11(9.6 \%) \\
\text { USA: } 9(7.8 \%) \\
\text { Egypt: } 8(6.9 \%) \\
\text { Netherlands: } 4(3.5 \%) \\
\text { Spain: } 2(1.7 \%)\end{array}$ \\
\hline $\begin{array}{l}\text { Co-morbid } \\
\text { conditions }\end{array}$ & $\begin{array}{l}\text { DM (Cumulative): } 81(77.14 \%) \\
\text { - DM-Type 1: } 2(1.9 \%) \\
\text { - DM-Type 2: } 33(31.4 \%) \\
\text { - DM -(Type NS): } 46(43.8 \%) \\
\text { Hypertension: } 31(29.5 \%) \\
\text { Cardiac Disease: } 10(9.5 \%) \\
\text { Renal disease (Cumulative): } 15(14.3 \%) \\
\text { ESRD: } 3(2.6 \%) \\
\text { Cancer: } 7(6.7 \%) \\
\text { Haematological malignancies: } 7(6.7 \%) \\
\text { H/o transplant: } 7(6.7 \%) \\
\text { Renal transplant } 5(4.8 \%) \\
\text { Immunosuppressive therapy: } 8(7.6 \%) \\
\text { Obesity: } 4(3.8 \%) \\
\text { Asthma: } 4(3.8 \%)\end{array}$ \\
\hline $\begin{array}{l}\text { Type of } \\
\text { COVID-19 } \\
\text { treatment } \\
\text { received }\end{array}$ & $\begin{array}{l}\text { Steroids (cumulative use): } 80(91.9 \%) \\
\text { Dexamethasone: } 48(55.2 \%) \\
\text { Other than dexamethasone steroid use: } \\
\quad 34(39.1 \%) \\
\text { Remdesivir: } 19(21.8 \%) \\
\text { Tocilizumab: } 10(11.5 \%) \\
\text { Hydroxychloroquine: } 3(3.4 \%) \\
\text { Antibiotics: } 15(17.2 \%) \\
\text { Antivirals: } 5(5.7 \%)\end{array}$ \\
\hline $\begin{array}{l}\text { Average } \\
\text { duration } \\
\text { between } \\
\text { COVID-19 } \\
\text { symptoms/ } \\
\text { diagnosis and } \\
\text { mucormycosis } \\
\text { (range) }\end{array}$ & 16.15 days (range: $2-90$ days) \\
\hline
\end{tabular}

\begin{tabular}{|c|c|}
\hline Parameters & Results \\
\hline $\begin{array}{l}\text { Symptoms } \\
\text { that lead to the } \\
\text { diagnosis of } \\
\text { mucormycosis }\end{array}$ & $\begin{array}{l}\text { Orbital symptoms: } 42(54.5 \%) \\
\text { Visual disturbances: } 38(49.3 \%) \\
\text { Peri-orbital / Facial Pain: } 36(46.8 \%) \\
\text { Nasal discharge/crusts: } 18(23.3 \%) \\
\text { Headache: } 15(19.5 \%) \\
\text { Facial swelling: } 14(18.2 \%) \\
\text { Fever: } 13(16.9 \%) \\
\text { Palate necrosis: } 5(6.5 \%) \\
\text { Dental pain/discharge: } 4(5.2 \%) \\
\text { Cough: } 3(3.9 \%) \\
\text { Dyspnea: } 7(9.1 \%)\end{array}$ \\
\hline $\begin{array}{l}\text { Sites of } \\
\text { mucormycosis }\end{array}$ & $\begin{array}{l}\text { A. Sinuses: } 77(79.4 \%) \\
\text { - Maxillary: } 46(47.4 \%) \\
\text { - Ethmoid: } 44(45.4 \%) \\
\text { - Sphenoid: } 25(25.8 \%) \\
\text { - Frontal: } 20(20.6 \%) \\
\text { - Sinus (Unspecified): } 16(16.5 \%) \\
\text { B. Orbit: } 55(56.7 \%) \\
\text { C. Nasal and adjacent structures: } \\
16(16.5 \%) \\
\text { D. Lungs: } 11(11.3 \%) \\
\text { E. Disseminated: two cases }(2.06 \%) \\
\text { F. Stomach: } 1(1.03 \%), \text { G. Skin: } 1(1.03 \%) \text {, } \\
\text { H. Muscle: } 1(1.03 \%)\end{array}$ \\
\hline Complications & $\begin{array}{l}\text { Cavernous sinus involvement: } \\
14(14.4 \%) \\
\text { Cerebral involvement: } 12(12.4 \%) \\
\text { Optic nerve involvement: } 4(4.1 \%) \\
\text { OCS: } 2(2.06 \%)\end{array}$ \\
\hline $\begin{array}{l}\text { Treatment for } \\
\text { mucormycosis }\end{array}$ & $\begin{array}{l}\text { Amphotericin B: } 79(85.9 \%) \\
\text { Posaconazole: } 16(17.4 \%) \\
\text { Isavuconazole: } 7(7.6 \%) \\
\text { Caspofungin:4 }(4.34 \%) \\
\text { Voriconazole: } 3(3.3 \%) \\
\text { Itraconazole: } 3(3.3 \%) \\
\text { Broad spectrum antibiotics: } 10(10.87 \%)\end{array}$ \\
\hline $\begin{array}{l}\text { Most common } \\
\text { surgery } \\
\text { performed for } \\
\text { mucormycosis }\end{array}$ & $\begin{array}{l}\text { Sino-nasal surgery (FESS, } \\
\text { debridement): } 55(59.8 \%) \\
\text { Orbital exenteration: } 13(14.1 \%)\end{array}$ \\
\hline Outcome & Mortality: 37 (48.7\%) \\
\hline
\end{tabular}

Abbreviations: $\mathrm{DM}=$ Diabetes Mellitus; $\mathrm{NS}=$ Not Specified; $\mathrm{OCS}=$ Orbital Compartment Syndrome; FESS= Functional Endoscopic Sinus Surgery. 
Table 2 - The patients' baseline characteristics and symptoms.

\begin{tabular}{|c|c|}
\hline Authors & Description of the patients and presenting symptoms \\
\hline Garg et al. [4] & $55 \mathrm{Y} / \mathrm{M}$ presented with productive cough \\
\hline Mehta et al. [5] & $60 \mathrm{Y} / \mathrm{M}$ presented with swelling of eyelids \& proptosis \\
\hline Werthman-Ehrenreich [6] & 33Y/F presented with cough, dyspnea, altered mental status \\
\hline Mekonnen ZK [7] & $60 \mathrm{Y} / \mathrm{M}$ presented with proptosis \\
\hline Monte Junior ESD et al. [8] & $86 \mathrm{Y} / \mathrm{M}$ presented with melena \\
\hline Alekseyev et al. [9] & 41Y/ M presented with black eschar on the palate \\
\hline Selarka et al. [10] & 42Y / M presented with headache, toothache, black discharge from nostril \\
\hline Pasero et al. [11] & $66 \mathrm{Y} / \mathrm{M}$ had worsening dyspnea \& pulmonary infiltrates \\
\hline Salomon Waizel-Haiat et al. [12] & 24Y /F had mid-facial pain, lid swelling \& maxillary hypoesthesia \\
\hline Veisi et al. [13] & 2 cases, aged $40 \& 54 \mathrm{Y}$, one male \& female, presented with orbital pain \& visual loss \\
\hline Maini A et al. [14] & 38Y/M presented with pain, swelling of left eye, proptosis \\
\hline Saldanha M et al. [15] & $32 \mathrm{Y} / \mathrm{F}$ presented with ptosis and facial pain \\
\hline Karimi-Galougahi M et al. [16] & $61 \mathrm{Y} / \mathrm{F}$ presented with hemifacial pain \\
\hline Johnson AK et al. [17] & $71 \mathrm{Y} / \mathrm{M}$ presented with fevers and shock \\
\hline Placik DA et al. [18] & $49 \mathrm{Y} / \mathrm{M}$ presented with worsening dyspnea \\
\hline Revannavar SM et al. [19] & Middle aged F presented with ptosis, facial pain and fever \\
\hline Krishna V et al. [20] & $22 \mathrm{Y} / \mathrm{M}$ was diagnosed at autopsy \\
\hline Meshram HS et al. [21] & 2 cases, males, aged $25 \& 47 \mathrm{Y}$, presented with fever, cough, black sputum \& headache \\
\hline Arana C et al. [22] & 2 cases, aged $62 \& 48 Y$, males, presented with headache, fever, leg pain \& swelling \\
\hline Jain M et al. [23] & $57 \mathrm{Y} / \mathrm{F}$ presented with abdominal pain, distention \& constipation \\
\hline Rao R et al. [24] & $66 \mathrm{Y} / \mathrm{M}$ presented with headache, periorbital pain \& loss of vision \\
\hline Zurl C et al. [25] & 53Y/M presented with fever \& respiratory distress \\
\hline Khatri A et al. [26] & $68 \mathrm{Y} / \mathrm{M}$ presented with a fluctuant swelling in axilla \\
\hline Bellanger et al. [27] & $55 \mathrm{Y} / \mathrm{M}$ presented with fever and respiratory distress \\
\hline Saidha PK et al. [28] & $\begin{array}{l}6 \text { cases, aged } 29-68 Y, \text { M: } 4 \text { F: 2, presented with facial pain, swelling, } \\
\text { headache were presenting complains }\end{array}$ \\
\hline Kanwar A et al. [29] & 56Y/M presented with fatigue, shortness of breath, and hemoptysis \\
\hline Ashour MM et al. [30] & 8 Cases, aged 41-67 Y, M: 5, F: 3, presented with eyelid edema, proptosis, drop of vision \\
\hline Sai Krishna D et al. [31] & 2 Cases, men, 34Y \& 50Y, presented with facial pain \& swelling \\
\hline Nehara HR et al. [32] & $\begin{array}{l}5 \text { cases, aged } 52-70 Y, F: 2, \text { M: } 3 \text {, presented with headache, visual loss, } \\
\text { bloody nasal discharge, ptosis }\end{array}$ \\
\hline Sen $\mathrm{M}$ et al. [33] & $\begin{array}{l}6 \text { cases, aged } 46-73 Y \text {, all were men, presented with pain, redness, periocular swelling, } \\
\text { ptosis \& proptosis }\end{array}$ \\
\hline Moorthy A et al. [34] & 18 cases, aged: $35-73 Y$, M: 15, F: 3 \\
\hline Dallalzadeh e al. [35] & 2 cases, $36 \& 48 Y$, males, presented with periorbital edema \& facial swelling \\
\hline Buil JB et al. [36] & $\begin{array}{l}4 \text { cases, ages ranging late } 50 \text { s to early } 70 \text { s, all were men. Presented with fever, } \\
\text { dyspnea, loss vision \& eye swelling }\end{array}$ \\
\hline Pakdel F et al. [37] & $\begin{array}{l}15 \text { Cases were reported, aged 32-71Y, M: } 12, \mathrm{~F}: 3 \text {, Headache, unilateral facial swelling } \\
\& \text { pain, eyelid edema, ptosis, proptosis, acute vision loss were the presenting symptoms }\end{array}$ \\
\hline Sarkar S et al. [38] & 10 cases. aged: $23-67 Y$, M: 8, F: 2. \\
\hline Bayram et al. [39] & 11 Cases, aged 61-88 Y, M: 9, F: 2. Presented with pain, proptosis and visual loss \\
\hline
\end{tabular}


out of 10 cardiac disease patients were reported to have cardiomyopathy. A total of 8 patients $(7.6 \%)$ were on chronic immunosuppressive therapy (excluding steroids that were prescribed to treat COVID-19) and 7 patients (6.7\%) had haematological malignancies. Seven patients $(6.7 \%)$ had a history of transplants and kidney transplantation was the most common among them. Asthma and obesity were present in $4(3.8 \%)$ patients each.

Eighty patients (91.9\%) had received some form of steroids to treat COVID-19 infection, $55.2 \%$ of these patients had received dexamethasone before the diagnosis of mucormycosis. Treatment with remdesivir and antibacterial therapy were reported in $19(21.8 \%)$ and $15(17.2 \%)$ patients respectively. A total of 10 patients $(11.5 \%)$ had received tocilizumab.

\section{Clinical characteristics}

Orbital symptoms such as orbital swelling, pain, proptosis, ptosis were the most common presenting symptoms that lead to the diagnosis of mucormycosis. Visual complaints such as decreased or loss of vision, blurry or double vision were seen in $49.3 \%$ of patients. Peri-orbital/facial pain and headache were seen in $36(46.8 \%)$ and 15 (19.5\%) patients respectively. Other symptoms include nasal discharge, nasal crusts, palate necrosis. Cough $(3.9 \%)$, hemoptysis $(1.3 \%)$, and worsening dyspnea $(9.1 \%)$ were seen in patients with pulmonary mucormycosis. Abdominal pain and distention were presenting symptoms in a patient with mesenteric mucormycosis.

In this review, we found that sinuses were the most common site of mucormycosis in COVID-19 patients at $79.4 \%$ with maxillary sinus $(47.4 \%)$ being most commonly infected followed by ethmoid $(45.4 \%)$ and sphenoid sinuses $(25.8 \%)$. Orbits were the second most prevalent site of infection at $56.7 \%$ and nasal mucosa was involved in 16 patients $(16.5 \%)$. Lungs were infected with mucor at $11.3 \%$. Disseminated mucormycosis was reported in two cases $(2.06 \%)$ and one case of gastric mucormycosis was found in 1 patient $(1.03 \%)$. Skin involvement was seen in a patient who presented with a fluctuant axillary lump. Another case described a case of mucormycosis involving muscle after he was diagnosed with compartment syndrome of a leg. The mean duration between the diagnosis of COVID-19 diagnosis and mucormycosis was 16.15 days (range 2-90 days).

\section{Complications and outcomes}

Cavernous sinus was either infiltrated or encased in 14 patients $(14.4 \%)$. Cerebral involvement was seen in terms of abscess, infarcts, or edema in 12 patients $(12.4 \%)$. The most common treatment that was given in COVID-19 patients diagnosed with mucormycosis was amphotericin B (85.9\%). Only 76 patients had data on the outcomes, out of which 37 (48.7\%) patients had died.

\section{DISCUSSION}

Mucormycosis is an opportunistic fungal infection that typically affects immunocompromised patients, and particularly patients with uncontrolled diabetics mellitus. The fungi that cause mucormycosis belong to the order Mucorales: Rhizopus, Mucor, Rhizomucor, Cunninghamella, and Absidia. Broad, irregularly branched with rare septations are seen on microscopy. These fungi are ubiquitously found everywhere particularly in soil and decaying vegetations and are routinely exposed to humans without causing any infections. Traditional risk factors that increase the chances of acquiring mucormycosis include diabetes mellitus, haematological malignancies, stem cell transplant, organ transplant, iron overload, treatment with deferoxamine, malnutrition, burns, extensive use of broad-spectrum antibiotics, critical care admissions [40]. These fungi are angioinvasive and cause thrombosis with the death of affected tissues.

Rhino-orbital-cerebral mucormycosis is the most commonly observed manifestation, followed by cutaneous and pulmonary mucormycosis. In a susceptible individual, mucormycosis is caused by the inhalation of spores and typically starts with acute sinusitis. Symptoms such as facial pain, nasal discharge, headache, fever, or nasal congestion may develop. The infection is typically aggressive involving adjacent structures causing necrosis of palate, turbinates, and other nasal structures. Orbital involvement can lead to visual loss, proptosis, orbital pain, discharge, and periorbital edema. Involvement of vascular structures such as carotid artery and cavernous sinus can also occur.

Fever and haemoptysis develop when pneumonia sets in with the inhalation of these fungal spores causing pulmonary infarction. Cutaneous mucormycosis is seen with the inoculation of fungal 
spores in the skin and subcutaneous tissue after major or minor trauma in a susceptible individual. Oral ingestion of spores can lead to necrotic ulcers, perforation, peritonitis, bowel infarction leading to abdominal pain, and haematemesis. Central nervous system can be involved with the contiguous spread from a sinus infection. Haematological malignancies are associated with an increased risk of a disseminated form of mucormycosis while a history of solid organ transplantation was associated with a higher risk of pulmonary and gastrointestinal manifestations of mucormycosis [41].

Endoscopic evaluation of sinuses and biopsies of involved sinuses and necrotic tissues is necessary to establish a diagnosis. Histopathological examination of broad, aseptate hyphae using calcofluor white and methenamine silver stains is confirmatory. Control or elimination of predisposing factors, antifungal therapy, and surgical therapy are the core aspects of treating mucormycosis. Liposomal amphotericin B is the initial drug of choice and is recommended at a dose of $5-10 \mathrm{mg} / \mathrm{kg}$ per day [42]. A dose of $3 \mathrm{mg} / \mathrm{kg} /$ day was also found to be equally effective in a randomized control trial [43]. Posaconazole and isavuconazole are typically used as step-down therapy after several weeks of treatment with amphotericin B or salvage therapy. Debridement of involved tissues can be extensive and disfiguring but are life-saving. Overall, the mortality rate varies from 31\% to $96 \%$ with the highest among the disseminated form of mucormycosis.

In our systematic review, similar to non-COVID-19 patients, diabetes mellitus was found to be the predominant co-morbidity among COVID-19 patients with mucormycosis. During the pre-pandemic era, the prevalence of diabetes mellitus in patients with mucormycosis was found to be $40 \%$ in a systematic review of 851 patients by Jeong et al. [44]. In our review, the prevalence of diabetes mellitus among COVID-19 patients with mucormycosis was much higher, i.e. $77.1 \%$.

As shown in Table 1, more than $90 \%$ of patients had received some form of steroids before the diagnosis of mucormycosis. Steroids have likely increased the risk of diabetic patients acquiring this opportunistic infection among COVID-19 patients. Steroids elevate blood sugar level which in turn causes glycosylation of transferrin and ferritin, decreases binding to iron and thereby increasing the amount of free iron. This, along with acidosis resulting from diabetic ketoacidosis, facilitates the germination of mucor spores. Suppression of phagocytic activity of leucocytes resulting from the steroids is also implicated in the pathogenesis [45]. Hypertension and cardiac disease were reported in nearly one-third and one-tenth of the cases respectively, but their role in the pathogenesis is unclear.

In our review, we also noted that mucormycosis was found in previously immunocompetent patients who were diagnosed with COVID-19 infection. This implies that different mechanisms do exist other than the already known ones and supports the concept of COVID-19 related immunosuppression in the pathogenesis of mucormycosis. Lymphopenia, suppression of CD4+ and CD8+ T-lymphocytes, and immune dysfunction are seen in COVID-19 infection. Endotheliatis, thrombosis, up-regulation of GRP 78 (glucose receptor protein -78), a receptor that facilitates fungal invasion, fungal ligand spore coating homolog $(\mathrm{CotH})$ protein facilitating fungal angioinvasion, hepcidin activation by SARS-CoV-2 glycoprotein leading to dysregulation of iron homeostasis and iron overload are some of the other mechanisms that explain the increased predisposition of COVID-19 patients to mucormycosis [45, 46].

Complications associated with COVID-19 patients were not uncommon. Vascular involvement such as cavernous sinus encasement, infiltration, thrombosis, vasculitis of the internal carotid artery was seen. Haematological dissemination to the brain with the development of the cerebral abscess and acute infarcts were also reported. Other complications included orbital compartment syndrome and or optic neuritis/optic nerve infiltration. Liposomal amphotericin B was the most common drug used in the treatment of mucormycosis among COVID-19 patients followed by posaconazole. Interestingly, the broad-spectrum antibacterial therapy was continued despite no evidence of bacterial infection in nearly $10 \%$ of the cases. Flexible endoscopic sinus surgery and debridement were the most common surgery performed and orbital exenteration was done in 13 patients (14.1\%).

A high mortality rate was observed in this study at $48.7 \%$ among COVID-19 patients. This also reiterates the deadly nature of this fungal infection. The high mortality could also be partly explained 
by the severity of the patients, poor availability of the antifungals, and saturated healthcare resources in developing countries during the second wave of the COVID-19 pandemic, where most of the cases were concentrated.

There are several limitations of this systematic review. About ten patients did not have details on co-morbid conditions. Similarly, a case series of eighteen patients did not have extensive granular details on the presentation and complications. It is also possible that the patients who presented are not aware of their status of immunosuppression and hence may not be reported. Further, the cases of mucormycosis may be underdiagnosed due to diagnostic challenges resulting from a decrease in specimen processing centers to avoid exposure to SARS-CoV-2.

In conclusion, in this systematic review, we found that diabetes mellitus is still the most common co-morbidity. More than $90 \%$ of the patients with COVID-19 infection had received steroids. Indiscriminate use of steroids in patients needs to be avoided and focus needs to be put on tight blood sugar control in diabetic patients. Complications such as cavernous sinus thrombosis, cerebral infarcts, and abscesses were common. Despite advances in medical and surgical treatment options, the mortality rate was significantly higher in these patients. Studies are needed to confirm the role of the SARS-CoV-2 virus in causing immune dysfunction and mucormycosis.

\section{Conflicts of interest}

None of the authors have any actual or potential conflicts of interest to disclose.

\section{Fundings}

None of the authors have any financial relationship to disclos

\section{REFERENCES}

[1] World Health Organization. WHO Coronavirus (COVID-19) Dashboard. Available at https:/ / covid19. who.int/ [Accessed October 15th, 2021].

[2] Sterne JAC, Diaz J, Villar J, et al. Corticosteroid therapy for critically ill patients with COVID-19: A structured summary of a study protocol for a prospective meta-analysis of randomized trials. Trials. 2020; 21 (1), 734. doi: 10.1186/s13063-020-04641-3.

[3] Sugar AM. Mucormycosis. Clin Infect Dis. 1992; 14 Suppl 1, S126-9. doi: 10.1093/clinids/14.supplement_1.s126.
[4] Garg D, Muthu V, Sehgal IS, et al. Coronavirus Disease (Covid-19) Associated Mucormycosis (CAM): Case Report and Systematic Review of Literature. Mycopathologia. 2021; 186 (2), 289-98. doi: 10.1007/s11046021-00528-2.

[5] Mehta S, Pandey A. Rhino-Orbital Mucormycosis Associated With COVID-19. Cureus. 2020; 12 (9), e10726. doi: 10.7759/cureus.10726.

[6] Werthman-Ehrenreich A. Mucormycosis with orbital compartment syndrome in a patient with COVID-19. Am J Emerg Med. 2021; 42, 264.e5-264.e8. doi: 10.1016/j. ajem.2020.09.032.

[7] Mekonnen ZK, Ashraf DC, Jankowski T, et al. Acute invasive rhino-orbital mucormycosis in a patient with COVID-19-associated acute respiratory distress syndrome. Ophthalmic Plast Reconstr Surg. 2021; 37 (2), e40e80. doi: 10.1097/IOP.0000000000001889.

[8] Monte Junior ESD, Santos MELD, Ribeiro IB, et al. Rare and fatal gastrointestinal mucormycosis (Zygomycosis) in a COVID-19 patient: a case report. Clin Endosc. 2020; 53 (6), 746-9. doi: 10.5946/ce.2020.180.

[9] Alekseyev K, Didenko L, Chaudhry B. Rhinocerebral mucormycosis and COVID-19 pneumonia. J Med Cases. 2021; 12 (3), 85-9. doi: 10.14740/jmc3637.

[10] Selarka L, Sharma AK, Rathod G, Saini D, Patel S, Sharma VK. Mucormycosis - A dreaded complication of Covid-19. QJM. 2021; hcab166. doi: 10.1093/qjmed/ hcab166.

[11] Pasero D, Sanna S, Liperi C, et al. A challenging complication following SARS-CoV-2 infection: a case of pulmonary mucormycosis. Infection. 2020; 17, 1-6. doi: 10.1007/s15010-020-01561-x.

[12] Waizel-Haiat S, Guerrero-Paz JA, Sanchez-Hurtado L, Calleja-Alarcon S, Romero-Gutierrez L. A case of fatal rhino-orbital mucormycosis associated with new onset diabetic ketoacidosis and COVID-19. Cureus. 2021; 13 (2), e13163. doi: 10.7759/cureus.13163.

[13] Veisi A, Bagheri A, Eshaghi M, et al. Rhino-orbital mucormycosis during steroid therapy in COVID-19 patients: A case report. Eur J Ophthalmol. 202; 11206721211009450. doi: 10.1177/11206721211009450.

[14] Maini A, Tomar G, Khanna D, Kini Y, Mehta H, Bhagyasree V. Sino-orbital mucormycosis in a COVID-19 patient: A case report. Int J Surg Case Rep. 2021; 82, 105957. doi: 10.1016/j.ijscr.2021.105957.

[15] Saldanha M, Reddy R, Vincent MJ. Paranasal mucormycosis in COVID-19 patient. Indian J Otolaryngol Head Neck Surg. 2021; 1-4. doi: 10.1007/s12070-021-02574-0.

[16] Karimi-Galougahi M, Arastou S, Haseli S. Fulminant mucormycosis complicating coronavirus disease 2019 (COVID-19). Int Forum Allergy Rhinol. 2021; 11 (6), 1029-30. doi: 10.1002/alr.22785. Epub 2021 Mar 13.

[17] Johnson AK, Ghazarian Z, Cendrowski KD, Persichino JG. Pulmonary aspergillosis and mucormycosis in a patient with COVID-19. Med Mycol Case Rep. 2021; 32, 64-7. doi: 10.1016/j.mmcr.2021.03.006. 
[18] Placik DA, Taylor WL, Wnuk NM. Bronchopleural fistula development in the setting of novel therapies for acute respiratory distress syndrome in SARS-CoV-2 pneumonia. Radiol Case Rep. 2020; 15 (11), 2378-81. doi: 10.1016/j.radcr.2020.09.026.

[19] Revannavar SM, Supriyga PS, Samaga L, Vineeth VK. COVID-19 triggering mucormycosis in a susceptible patient: a new phenomenon in the developing world? BMJ Case Rep. 2021; 14 (4), e241663. doi: 10.1136/ bcr-2021-241663.

[20] Krishna V, Morjaria J, Jalandari R, Omar F, Kaul S. Autoptic identification of disseminated mucormycosis in a young male presenting with cerebrovascular event, multi-organ dysfunction and COVID-19 infection. IDCases. 2021; 25, e01172. doi: 10.1016/j. idcr.2021.e01172.

[21] Meshram HS, Kute VB, Chauhan S, Desai S. Mucormycosis in post-COVID-19 renal transplant patients: A lethal complication in follow-up. Transpl Infect Dis. 2021; e13663. doi: 10.1111/tid.13663.

[22] Arana C, Cuevas Ramírez RE, et al. Mucormycosis associated with COVID-19 in two kidney transplant patients. Transpl Infect Dis. 2021; e13652. doi: 10.1111/tid.13652.

[23] Jain M, Tyagi R, Tyagi R, Jain G. Post-COVID-19 Gastrointestinal Invasive Mucormycosis. Indian J Surg. 2021; 1-3. doi: 10.1007/s12262-021-03007-6.

[24] Rao R, Shetty AP, Nagesh CP. Orbital infarction syndrome secondary to rhino-orbital mucormycosis in a case of COVID-19: Clinico-radiological features. Indian J Ophthalmol. 2021; 69 (6), 1627-30. doi: 10.4103/ijo. IJO_1053_21.

[25] Zurl C, Hoenigl M, Schulz E, et al. Autopsy proven pulmonary mucormycosis due to Rhizopus microsporus in a critically ill COVID-19 patient with underlying hematological malignancy. J Fungi (Basel). 2021; 7 (2), 88. doi: $10.3390 /$ jof7020088.

[26] Khatri A, Chang KM, Berlinrut I, Wallach F. Mucormycosis after Coronavirus disease 2019 infection in a heart transplant recipient - Case report and review of literature. J Mycol Med. 2021; 31 (2), 101125. doi: 10.1016/j.mycmed.2021.101125.

[27] Bellanger AP, Navellou JC, Lepiller Q, et al. Mixed mold infection with Aspergillus fumigatus and Rhizopus microsporus in a severe acute respiratory syndrome Coronavirus 2 (SARS-CoV-2) patient. Infect Dis Now. 2021; 2021; 51 (7), 63335. doi: 10.1016/j.idnow.2021.01.010.

[28] Saidha PK, Kapoor S, Das P, et al. Mucormycosis of paranasal sinuses of odontogenic origin post COVID19 infection: a case series. Indian J Otolaryngol Head Neck Surg. 2021; 17, 1-5. doi: 10.1007/s12070-021-02638-1.

[29] Kanwar A, Jordan A, Olewiler S, Wehberg K, Cortes M, Jackson BR. A fatal case of Rhizopus azygosporus pneumonia following COVID-19. J Fungi (Basel). 2021; 7 (3), 174. doi: 10.3390/jof7030174.
[30] Ashour MM, Abdelaziz TT, Ashour DM, Askoura A, Saleh MI, Mahmoud MS. Imaging spectrum of acute invasive fungal rhino-orbital-cerebral sinusitis in COVID-19 patients: A case series and a review of literature. J Neuroradiol. 2021; 48 (5), 319-324. doi: 10.1016/j.neurad.2021.05.007.

[31] Sai Krishna D, Raj H, Kurup P, Juneja M. Maxillofacial infections in Covid-19 era-actuality or the unforeseen: 2 case reports. Indian J Otolaryngol Head Neck Surg. 2021; 17, 1-4. doi: 10.1007/s12070-021-02618-5.

[32] Nehara HR, Puri I, Singhal V, Ih S, Bishnoi BR, Sirohi P. Rhinocerebral mucormycosis in COVID-19 patient with diabetes a deadly trio: Case series from the northwestern part of India. Indian J Med Microbiol. 2021; 39 (3), 380-3. doi: 10.1016/j.ijmmb.2021.05.009.

[33] Sen M, Lahane S, Lahane TP, Parekh R, Honavar SG. Mucor in a viral land: a tale of two pathogens. Indian J Ophthalmol. 2021; 69 (2), 244-52. doi: 10.4103/ijo. IJO_3774_20.

[34] Moorthy A, Gaikwad R, Krishna S, et al. SARSCoV-2, Uncontrolled diabetes and corticosteroids-an unholy trinity in invasive fungal infections of the maxillofacial region? A Retrospective, Multi-centric Analysis. J Maxillofac Oral Surg. 2021; 20 (3), 1-8. doi: 10.1007/ s12663-021-01532-1.

[35] Dallalzadeh LO, Ozzello DJ, Liu CY, Kikkawa DO, Korn BS. Secondary infection with rhino-orbital cerebral mucormycosis associated with COVID-19. Orbit. 2021; 1-4. doi: 10.1080/01676830.2021.1903044.

[36] Buil JB, van Zanten ARH, Bentvelsen RG, et al. Case series of four secondary mucormycosis infections in COVID-19 patients, the Netherlands, December 2020 to May 2021. Euro Surveill. 2021; 26 (23), 2100510. doi: 10.2807/1560-7917.ES.2021.26.23.2100510.

[37] Pakdel F, Ahmadikia K, Salehi M, et al. Mucormycosis in patients with COVID-19: A cross-sectional descriptive multicentre study from Iran. Mycoses. 2021; 64 (10), 1238-52. doi: 10.1111/myc.13334. doi: 10.1111/ myc. 13334 .

[39] Bayram N, Ozsaygılı C, Sav H, et al. Susceptibility of severe COVID-19 patients to rhino-orbital mucormycosis fungal infection in different clinical manifestations. Jpn J Ophthalmol. 2021; 65 (4), 515-25. doi: 10.1007/s10384-021-00845-5.

[40] Bhandari J, Thada PK, Nagalli S. Rhinocerebral Mucormycosis. [Updated 2021 Jul 7]. In: StatPearls [Internet]. Treasure Island (FL): StatPearls Publishing; 2021 Jan.

[41] Jeong W, Keighley C, Wolfe R, et al. The epidemiology and clinical manifestations of mucormycosis: a systematic review and meta-analysis of case reports. Clin Microbiol Infect. 2019; 25 (1), 26-34. doi: 10.1016/j. cmi.2018.07.011.

[42] Cornely OA, Alastruey-Izquierdo A, Arenz D, et al. Global guideline for the diagnosis and management of mucormycosis: an initiative of the European confedera- 
tion of medical mycology in cooperation with the mycoses study group education and research consortium. Lancet Infect Dis. 2019; 19 (12), e405-e21. doi: 10.1016/ S1473-3099(19)30312-3.

[43] Muthu V, Agarwal R, Dhooria S, et al. Has the mortality from pulmonary mucormycosis changed over time? a systematic review and meta-analysis. Clin Microbiol and Infect. 2021; 27 (4), 538-49. doi: 10.1016/j. cmi.2020.12.035.

[44] Jeong W., Keighley C., Wolfe R. The epidemiology and clinical manifestations of mucormycosis: a systematic review and meta-analysis of case reports. Clin $\mathrm{Mi}$ crobiol Infect. 2019; 25, 26-34.

[45] Singh AK, Singh R, Joshi SR, Misra A. Mucormycosis in COVID-19: A systematic review of cases reported worldwide and in India. Diabetes Metab Syndr. 2021; 15 (4), 102146. doi:10.1016/j.dsx.2021.05.019

[46] Baldin C., Ibrahim A.S. Molecular mechanisms of mucormycosis - The bitter and the sweet. PLoS Pathog. 2017; 13 (8), e1006408. 